Down Syndrome Research and Practice Vol. 5, No. 3, pp 117 - 119

(C) The Down Syndrome Educational Trust

Printed in Great Britain. All Rights Reserved.

ISSN: 0968-7912 (1998) 5:3

\title{
INCIDENCE OF HELICOBACTER PYLORI ANTIBODIES IN SUBJECTS WITH DOWN SYNDROME*
}

\author{
Pinella Failla, Rosa Pettinato, Concetta Barone, Corrado Romano. \\ Oasi Institute, Troina, Italy.
}

The Helicobacter pylorus (HP) is a Gram-negative bacterium that colonizes the antral portion of the stomach. It is the major aetiological agent responsible for chronic gastritis, gastric and duodenal ulcer disorders. This bacterium is widespread within the adult population $(36.9 \%-53 \%)$, and the incidence of infection is positively correlated with age $16-20 \%$ in paediatric populations of Western Europe). The higher frequency among subjects with immunodeficiency and poor hygienic conditions has been pointed out. People with Down syndrome show higher susceptibility to this infection. The present study deals with the serological assay of $\lg G$ antibodies to HP in subjects with Down syndrome. We evaluated 77 subjects with Down syndrome, sex ratio $M: F, 1: 3$, aged 1 to 40.7 years (mean 13.5). All were assayed for IgG antibodies to HP by the ELISA method. Subjects were separated into two groups according to age. The first group was made up of 46 subjects aged up to 14 years, and the second group contained 31 subjects over 14 years of age. Nine subjects $(19.5 \%)$ in the first group and 16 subjects $(51.6 \%)$ in the second group showed an antibody titre compatible with HP infection. The incidence in the whole sample of 77 subjects with Down syndrome was $32.4 \%$. Therefore, people with Down syndrome do not seem to show a higher susceptibility to HP infection.

Keywords: Down syndrome, helicobacter pylori, IgG

* From a paper presented at the 6th World Congress on Down Syndrome, Madrid, Spain, October 1997.

\section{Introduction}

The Helicobacter pylori (HP) is a motile gramnegative bacterium, which has a flagellum and colonizes the antral portion of the stomach, multiplying within the mucus in the crypts and adhering to the epithelium, where it has a cytotoxic effect. It is considered to be the major aetiological agent responsible for antral gastritis, duodenal and gastric ulcers. Furthermore, it seems to play an important role in the pathogenesis of gastric cancer (Warren \& Marshall, 1983;

Parsonnet, Friedman, \& Vandersteen, 1991; Newell, 1991; Blaser, 1992). HP infection has a world-wide distribution, with a variable incidence. It has an equal sex ratio, but the incidence is higher among blacks, Hispanics and in developing countries (Mégrand, 1989; Malaty, Evans, Evans, \& Graham, 1992). Recently, epidemiological surveys have been extended to the paediatric population, and the frequency of people with high levels of antibodies to HP has been reported to increase with age (Perez-Perez, Dworkin, Chodos, \& Blaser, 1988; Blecker, Keymolen, Lanciers, Bahwere, Sonayah, et al., 1994). The HP infection rate is higher among children from developing countries (Mégrand, 1989). Epidemiological surveys carried out in Western countries show a rate of HP infection ranging from 6 to $20 \%$ in unselected paediatric populations (Lindkvist, Asrat, Nilsson, Tsega, Olsson, et al., 1996; Rigillo, Francavilla, \& Rutigliano, 1996; Granstrom, Tindberg, \& Blennow, 1997) reaching values from 36.9 to $53 \%$ 
in adults (Glasbrenner, Malfertheiner, Nilius, Steinbruck, Bruckel et al., 1996; Martin de Argila, Boixeda, Canton, Mir, de Rafael et al., 1996). The incidence of HP is considerably higher among subjects with immunodeficiency and poor hygienic conditions (Blecker, Lanciers, Hanser, \& Vandenplas, 1994). Down syndrome is associated with a defect of the immune function (Ugazio, Maccario, Notarangelo, \& Burgio, 1990). In the present study, we evaluated the incidence of HP infection among subjects with Down syndrome, followed up in our Department, by assaying the level of HP antibodies. We ruled out people in institutions (Mégrand, Bounet, Garbier, \& Lamouliatte, 1985). The higher incidence of HP infection inside closed communities has already been demonstrated.

\section{Subjects and Methods}

We evaluated 77 subjects with Down syndrome, 44 males and 33 females (sex ratio M/F: 1.3), aged 1 to 40.7 years (mean age: 13.5 years). All were assayed for IgG antibodies to HP by the ELISA method. (Helori-test, Eurospital Pharma, Trieste, Italy). Values above $9 \%$ for children (0-14 years) and above $22 \%$ for adults (over 14 years) were considered positive for HP infection. Subjects were separated into two groups according to age. The first group was made up of 46 subjects aged up to 14 years (mean age 7.6 years), and the second group consisted of 31 subjects aged over 14 years (mean age 22.2 years).

\section{Results}

Nine subjects (19.5\%) in the first group showed an antibody titre compatible with HP infection and sixteen subjects $(51.6 \%)$ in the second group had an antibody titre compatible with HP infection. The incidence of the whole sample of 77 subjects with Down syndrome was $32.4 \%$.

\section{Discussion}

We believe that our results are meaningful, because the sample is made up of an adequate number of unselected subjects with Down syndrome, who were not institutionalised, but who were equally distributed for sex and separated in two age groups of similar size. The incidence of HP infection as determined by the serum assay of antibodies is not very different from that reported in epidemiological surveys performed on unselected populations from Western European countries. We would like to investigate the implications of this finding by relating antibody titres to endoscopy and histological findings. The aim of this last correlation would be to search for the same discrepancy between antibody response and mucosal lesions already reported in the general population.

\section{Correspondence:}

Dr. Corrado Romano, Department of Pediatrics, Oasi Institute, Via Conte Ruggero, 73, 94018 Troina (EN), Italy. (Phone 39-935-936111, Fax 39-935-653327, E-mail cromano@oasi.en.it) 


\section{References}

Blaser, M.J. (1992). Hypotheses on pathogenesis and natural history of Helicobacter pylori-induced inflammation. Gastroenterology, 102, 720-727.

Blecker, U., Keymolen, K., Lanciers, S., Bahwere, P., Sonayah, H \& Levy, J. (1994). The prevalence of Helicobacter pylori positivity in human immunodeficiency virus-infected children. Journal of Pediatric Gastroenterology and Nutrition, 19, 417-420.

Blecker, U., Lanciers, S., Hanser, B. \& Vandenplas, Y. (1994). The prevalence of Helicobacter pylori positivity in a symptom-free population, aged 1 to 40 years. Journal of Clinical Epidemiology, 47, 10951098.

Glasbrenner, B., Malfertheiner, P., Nilius, M., Steinbruck, C., Bruckel, J., Wiesneth, M. \& Adler, G. (1996). Prevalence of Helicobacter pylori infection and dyspepsia in young adults in Germany. Zeitschrift fur Gastroenterologie, 34, 478-482.

Granstrom, M., Tindberg, Y. \& Blennow, M. (1997). Seroepidemiology of Helicobacter pylori infection in a cohort of children monitored from 6 months to 11 years of age. Journal of Clinical Microbiology, 35, 468-470.

Lindkvist, P., Asrat, D., Nilsson, I., Tsega, E., Olsson, G.L., Wretlind, B. \& Giesecke, J (1996). Age at acquisition of Helicobacter pylori Ïnfection: comparison of a high and low prevalence country.

Scandinavian Journal of Infectious Diseases, 28, 181-184.

Malaty, H.M., Evans, D.G., Evans, D.J. \& Graham, D.Y. (1992). Helicobacter pylori in Hispanics: comparison with blacks and whites of similar age and socioeconomic class. Gastroenterology, 103, 813816.

Martin de Argila, C., Boixeda, D., Canton, R., Mir, N., de Rafael, L., Gisbert, J., Arocena, C. \& GarciaPlaza, A. (1996). Helicobacter pylori infection in a healthy population in Spain. European Journal of Gastroenterology and Hepatology, 8, 1165-1168.

Mégrand, F., Bounet, F., Garbier, M. \& Lamouliatte, H. (1985). Characterisation of Campylobacter piloridis by culture, enzymatic profile and protein content. Journal of Clinical Microbiology, 22, 10071010.

Megrand, F. (1989). Seroepidemiology of Campylobacter pylori infection in various populations. Journal of Clinical Microbiology, 27, 1870-1873.

Newell, D.G. (1991). Virulence factors of Helicobacter pylori. Scandinavian Journal of Gastroenterology, 26, 31-38.

Parsonnet, J., Friedman, G.D. \& Vandersteen, D.P. (1991). Helicobacter pylori infection and the risk of gastric carcinoma. New England Journal of Medicine, 325, 1127-1131.

Perez-Perez, G.I., Dworkin, B.M., Chodos, J.E. \& Blaser N.J. (1988). Campylobacter pylori antibodies in humans. Annals of Internal Medicine, 109, 11-17.

Rigillo, N., Francavilla, R. \& Rutigliano, V. (1996). Helicobacter pylori infection in childhood (editorial). Minerva Pediatrica, 48, 1-9.

Ugazio, A.G., Maccario, R., Notarangelo, L.D. \& Burgio, G.R (1990). Immunology of Down Syndrome: A Review. American Journal of Medical Genetics, Suppl 7, 204-212.

Warren, J.R. \& Marshall, B.J. (1983). Unidentified curved bacilli on gastric epithelium in active chronic gastritis. Lancet, i, 1273-1274. 